\title{
TAKING Roll: AN ASSESSMENT OF STATE AND LoCAL Governance of School Wellness Policies
}

\author{
Comment
}

Sally Hubbard ${ }^{*}$

\section{TABLE OF CONTENTS}

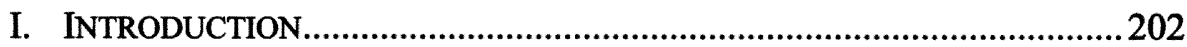

II. YOUTH OBESITY AND OVERWEIGHT: THE GLOBAL EPIDEMIC

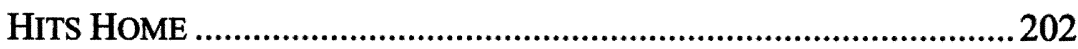

A. Expanding Waste Lines on Our Nation's Playgrounds: The Alarming Reality ......................................................... 203

B. Youth Obesity and Overweight: The Social and Economic Costs.

III. THE PREVENTATIVE Role OF STATE GoverNMENT AND

LOCAL SCHOOL DISTRICTS: A SHIFT AWAY FROM

OMNIPOTENT FEDERAL CONTROL

A. The Block Controversy .......................................................... 205

B. Pouring Contracts: Children Gain Weight While

Schools Earn Pennies on the Dollar

IV. NUTRITION AND PHYSICAL ACTIVITY: ESTABLISHING

EFFECTIVE POLICY

A. Crafting School Health Policies: An Art And a Science

$B$. Time, Talent, and Resources: Recognizing the

Problem is Only Half the Battle.

C. State Attempts to Resolve the Youth Obesity Crisis:

Legislative Mandate is the Key

V. CREATING A SOLUTION TO THE CRISIS OF YOUTH OBESITY

AND OVERWEIGHT

A. Funding is Important but Real Change Will Necessitate a Paradigm Shift

B. The CDC's Efforts to Change National Preconceptions About Youth Obesity and Overweight: The Social-Ecological Model......

C. The CDC Wages War on Obesity ........................................ 212

VI. CONCLUSION.

* J.D. Candidate, 2008, Health Law Concentration, Indiana University School of Law Indianapolis; M.Ed., 2000, University of Georgia; B.A., 1999, Indiana University. I would like to thank my mom, Ann Lawrence, for her unconditional love and support. This comment is dedicated to the three loves of my life, Grant, Kierstyn, and Hannah Hubbard: May you never lose your passion for physical activity. 


\section{INTRODUCTION}

During a lecture at the University of South Carolina, former U.S. Surgeon General Richard Carmona stated, "Obesity is the terror within. Unless we do something about it, the magnitude of the dilemma will dwarf $9 / 11$ or any other terrorist attempt.". Dr. Carmona added that childhood obesity impacts not only children's personal health, but also society as a whole. Indeed,“[w]here will our policemen and firemen come from if the youngsters today are on a trajectory that says they will be obese, laden with cardiovascular disease, increased cancers and a host of other diseases when they reach adulthood?"2

Carmona's provocative words - analogizing obesity to terrorism-elicit wide-ranging, often emotional, responses. Some contingents argued that personal behavioral choices should not be legislated, while other groups lobbied hard for tougher more uniform state laws requiring schools to intervene in America's obesity crisis. ${ }^{3}$ Consequently, the "emerging patchwork quilt of laws" relating to public schools' duty to serve as parent, counselor, and food police is a hodgepodge. ${ }^{4}$ As a result, states are left with little guidance and minimal incentive to create and enforce effective school nutrition and physical activity policies. ${ }^{5}$ This Comment will explore how local school wellness policies are both determined and affected by the expanding regulatory practices of state governments and the rapidly shifting political climates in which they exist. It will also explore various solutions suggested by: (1) current scientific literature; (2) applicable social-ecological models; and (3) the potential for state and local governments to strengthen their legislative influence in the public school arena by promoting the dissemination of physical activity initiatives, public health interventions, and strategies designed to improve the evidence-base for theoretically sound wellness policies and programs.

\section{YOUTH OBESITY AND OVERWEIGHT: THE GLOBAL EPIDEMIC HITS HOME}

In recent years, the one-two punch of skyrocketing youth obesity and overweight, and the increased incidence of the weight-related medical conditions that accompany them, have been keenly felt in the United States. ${ }^{6}$

1. Katrina A. Jackson, Surgeon General: Obesity 'terror within, 'Boston GLOBE, Mar. 1, 2006, available at http://www.boston.com/yourlife/health/diseases/articles/2006/03/01/ surgeon_general_obesity_terror_within/(last visited Feb. 10, 2008).

2. Id.

3. See generally Michele Simon \& Ellen J. Fried, State Laws on School Vending: The Need for a Public Health Approach, 62 FOOD \& DRUG L.J. 139, 139 (2007) (discussing variations in state wellness legislative activity).

4. Id. at 139.

5. See generally id.

6. See Jeffrey Levi et al., $F$ as in Fat: How Obesity Policies are Failing in America, ISSUE REP. (Trust for Am. Health, Washington, D.C.), Aug. 2007, at 3-4, available at 


\section{A. Expanding Waste Lines on Our Nation's Playgrounds: The Alarming Reality}

In the United States, the problem of youth obesity and overweight is currently so profound that it might rightly be regarded as a plague on America's present and future citizenry. ${ }^{7}$ In 2007 , for example, the nonpartisan organization, Trust for America's Health, reported that, in 2006, obesity rates rose in thirty-one U.S. states, ${ }^{8}$ but indicated that no states decreased their obesity rates during that year. Medically, this report is alarming, because youth obesity increases children's risk of developing type-two-diabetes, increased cholesterol, hypertension, and sleep apnea. ${ }^{9}$ Similarly, youth overweight may lead to orthopedic problems and premature menarche. ${ }^{10}$ The report is also alarming from a sociological standpoint, however, because childhood obesity and overweight, at any stage of development, may also negatively impact children's mental health and school performance. ${ }^{11}$ These negative impacts are problematic, not only because they suggest that the obesity epidemic effectively spans the childhood and adolescent continuum, but also because it suggests a trend toward increased socio-educational pressures and health care costs generally, a trend likely to affect all Americans on a basic economic level.

Given the considerations discussed above, it is clear that youth overweight and obesity can dramatically influence not only children's personal, interpersonal, and educational development, but also national economics. This revelation suggests that youth obesity and overweight should be considered, as indicated by U.S. Surgeon General Richard Carmona, a dire threat to the nation's future. ${ }^{12}$ To confront this threat, however, it must first be made recognizable; thus, a standardized definition for youth obesity and overweight should be determined.

Unfortunately, youth overweight and obesity - terms frequently tossed around by the media - are not easily definable. For adults, obesity is defined as "an excessively high amount of body fat or adipose tissue in relation to lean body mass." 13 As such, adult overweight refers to increased body weight in relation to height, as defined by the Body Mass Index ("BMI"), which uses height and weight in a specialized formula to come up with a single ratio of weight-to-height. ${ }^{14}$ In children, however, a modified BMI scale must be used,

http:/healthyamericans.org/reports/obesity2007/Obesity2007Report.pdf.

7. Id. at 3.

8. Id.

9. Mayo Clinic STAFF, Childhood Obesity: Complications (2006), http://www.mayo clinic.com/health/childhood-obesity/DS00698/DSECTION=6 (last visited Feb. 10, 2008).

10. Id.

11. See Jeffrey Levi et al., $F$ AS IN FAT: HoW OBESITY POLICIES ARE FAILING IN AMERICA, ISSUE REP. (Trust for Am. Health, Washington, D.C.), Aug. 2006, at 12, 20, http://healthyameri cans.org/reports/obesity2006/Obesity2006Report.pdf.

12. Jackson, supra note 1.

13. Levi et al., supra note 11 , at 12.

14. Body-mass-index (BMI) uses height and weight in a specialized formula to come up with a single ratio of weight-to-height. See id. 
which takes into account normal differences in body fat between boys and girls at different ages. ${ }^{15}$ Utilizing this modified scale, a youth may be considered overweight or obese if, taking into account height, age, and gender, he or she exhibits a BMI that is abnormally high, as compared to other children in his or her age group. ${ }^{16}$

\section{B. Youth Obesity and Overweight: The Social and Economic Costs}

Utilizing the BMI measurement approach outlined above, to define youth obesity and overweight, the Center for Disease Control ("CDC") has determined that "[s]ince 1976, the percentage of overweight children aged 6 to 1 [in the United States] has nearly tripled and the percentage of overweight adolescents ages 12 to 19 more than tripled. ${ }^{17}$ As a result, it is clear that obesity is not just an individual problem: Annual hospital costs related to treating childhood obesity from 1979 to 1981 were thirty-five million dollars (calculated in 2001 dollars), a dollar amount that increased to one hundred and twenty-seven million between the years 1997 and 1999. ${ }^{18}$

Clearly, youth overweight and obesity-related expenses will affect current and future generations of American citizens. These expenses, however, will not be confined to the treatment of children. Indeed, studies show that obese children are likely to become obese adults. ${ }^{19}$ The social costs of this transformation-loss of future wages and a reduction in our natural resource basecombined with the social opprobrium and the increased healthcare expenses associated with obesity, necessitate and reflect the urgency of a deeper exploration of states' roles in addressing public health crises through public schools. This position is supported by a recent position statement issued by the American Heart Association. In pertinent part, that statement concluded that public schools "could become the central element in a community system that ensures that students participate in enough physical activity to develop healthy lifestyles."20

15. See id.

16. See id.

17. Balance: A Report on State Action to Promote Nutrition, Increase Physical Activity and Prevent Obesity, MID-YeAR OVERVIEW (Robert Wood Johnson Found., Princeton, N.J.), July 2006, at 4, available at http://rwjf.org/pdf/Balance072006 (last visited Feb. 10, 2008).

18. U.S. Dept. of Health \& Human Services, Preventing Chronic Diseases: Investing Wisely in Health and Preventing Obesity and Chronic Diseases Through GOOD NUTRITION AND PHYSICAL ACTIVITY 1 (2005), available at http://www.healthierus.gov/ steps/summit/prevportfolio/PA-HHS.pdf.

19. AM. HEART ASs'N, FIT KIDS ACT, http://www.americanheart.org/presenter.jhtml?id entifier $=3010851$ (last visited Feb. 10, 2008).

20. Russell R. Pate et al., Promoting Physical Activity in Children and Youth: A Leadership Role for Schools, 114 CIRCULATION 1214, 1215 (2006), available at http://circ.ahajournals.org/cgi/reprint/1 14/1 1/1214?maxtoshow=\&HITS=10\&hits=10\&RESULT FORMAT $=\&$ fulltext $=$ Russell + R. + Pate\&searchid $=1 \&$ FIRSTINDEX $=0 \&$ resourcetype $=$ HWCIT . 


\section{THE PREVENTATIVE ROLE OF STATE GOVERNMENT AND LOCAL SCHOOL DISTRICTS: A SHIFT AWAY FROM OMNIPOTENT FEDERAL CONTROL}

\section{A. The Block Controversy}

State government and local school districts play increasingly important roles in regulating school vending and physical activity laws. The shift from omnipotent federal control of school nutrition and physical activity to state and local control began in 1983, with the seminal U.S. Court of Appeals case $\mathrm{Na}$ tional Soft Drink Ass'n v. Block. ${ }^{21}$ In Block, the National Soft Drink Association (now the American Beverage Association) sued the Secretary of Agriculture, who had prohibited the sale of soft drinks, in schools federally funded by the Child Nutrition Act of 1966, until the last meal service of the school day. ${ }^{22}$

The Block court held that the Secretary of Agriculture went beyond the scope of his rulemaking authority when he promulgated "time and place regulations" barring the sale of competitive foods throughout the school until after the end of the last meal service of the day. ${ }^{23}$ As a result, the Child Nutrition Act of 1966 was amended to reflect the court's decision, and sugary soft drinks - in addition to other foods of minimal nutritional value ("FMNV"), such as snack foods and fast foods-were allowed in public schools throughout the day. ${ }^{24}$ The National Soft Drink Association's victory was indeed the Secretary of Agriculture's loss; federal regulatory efforts were drastically weakened, and state and local governments were left scrambling to pick up the pieces and create their own laws regarding school nutrition and physical activity. ${ }^{25}$

\section{B. Pouring Contracts: Children Gain Weight While Schools Earn Pennies on the Dollar}

After the Block decision, beverage companies quickly swooped in seeking to establish exclusive "pouring rights" contracts with public school corporations. ${ }^{26}$ Not surprisingly, children's soft drink consumption more than doubled

21. See generally Natl. Soft Drink Ass'n v. Block, 721 F.2d 1348, 1348 (D.C. Cir. 1983).

22. Id. at 1350 (The Secretary of Agriculture promulgated regulations prohibiting "the sale of soda water (soda pop), water ices, chewing gum, and certain candies, throughout the public schools . . . until after the last lunch meal of the day.").

23. Id. at 1353 ("[T] he Secretary exceeded his rule making authority when he promulgated the time and place regulations barring the sale of competitive foods throughout the school and until after the end of the last service of the day.").

24. Id. at 1348 .

25. See id.

26. See generally Ellen Fried \& Michele Simon, The Competitive Food Conundrum: Can Government Regulations Improve School Food?, 56 DuKE L.J. 1491, 1491 (2007). 
in less than twenty-five years. ${ }^{27}$ By 2004 , "75 percent of high schools, 65 percent of middle schools, and 30 percent of elementary schools had 'pouring rights' contracts." 28 While schools have relied on these beverage contracts to support shrinking budgets, a recent study conducted by the Center for Science in the Public Interest ("CSPI") and the Public Health Advocacy Institute ("PHAI") ${ }^{29}$ lead the Robert Wood Johnson Foundation to discount the myth of the beverage company as school financial savior. ${ }^{30}$ The CSPI/PHAI study, which analyzed 120 contracts in 16 states, concluded that such beverage contracts raised less than $\$ 20$ per student annually. ${ }^{31}$ Furthermore, it determined that most soft drink revenue generated by in school sales - sixty-seven percent-typically benefits beverage companies. ${ }^{32}$ In pertinent part, the report states: "This means children (and, by extension, their parents) have to spend one dollar for their school to raise 33 cents.",33

The harmful effects of pouring contracts notwithstanding, the effects of the contracts are not completely adverse when effectively mediated by private third parties. For example, the American Beverage Association, whose membership includes the Cadbury-Schweppes, Coca-Cola, and PepsiCo corporations is currently providing healthier drinks such as milk and water to public schools because of an agreement with the Alliance for a Healthier Generation, a collaboration between the William J. Clinton Presidential Foundation and the American Heart Association. In the agreement, the sale of high calorie drinks in schools will be phased out, and smaller bottle sizes will be introduced. Moreover, the Alliance and the dairy industry reached an agreement to introduce into schools flavored milks lower in sugar. ${ }^{34}$ Such third party partnerships and alliances may be beneficial in decreasing children's soft drink consumption in schools regardless of the existence of pouring contracts; however, this private regulation may not be enough. Participation in such agreements is voluntary for schools, and typically includes long phase-in periods. ${ }^{35}$ During these transi-

27. S.J. Nielsen \& B.M. Popkin, Changes in Beverage Intake Between 1977 and 2001, 27 AM. J. PreVentative Med. 205, 207 (2004).

28. Fried \& Simon, supra note 26, at 1494.

29. Joy Johnson et al., Raw Deal: School Beverage Contracts More Lucrative Than They Seem, REP. (Ctr for Sci. in the Pub. Interest, Washington, D.C.), Dec. 2006, at iv, available at http://www.cspinet.org/beveragecontracts.pdf.

30. ROBERT WOOD JOHNSON Found., StUdy Suggests SOda Pop CONTRACTS ARE MOSTLY BUBBLES, FEw BUCKS (2006), http://www.rwjf.org/programareas/features/feature.jsp? id=21123\&typeid=151 [hereinafter SODA POP CONTRACTS] (last visited Feb. 10, 2008).

31. Johnson et al., supra note 29 , at iv.

32. Id.

33. SODA POP CONTRACTS, supra note 30.

34. ALLIANCE FOR A HEALTHIER GENERATION, SCHOOL BEVERAGES, http://www. healthiergenertion.org/companies.aspx?id=1376\&ekmensel=1ef02451_40_116_btnlink (last visited Feb. $10,2008)$.

35. Michelle M. Mello et al., The Interplay of Public Health Law and Industry SelfRegulation: The Case of Sugar-Sweetened Beverage Sales in Schools, 97 AM. J. PUB. HEALTH 13 (2007), available at $\mathrm{http}: / / \mathrm{www} . a j p h . o r g / c g i / d o i / 10.2105 / \mathrm{AJPH} .2006 .107680$ (last visited Feb. 10, 2008). 
tional periods, existing beverage contracts which adversely affect the health and wellbeing of America's youth must be followed unless schools are willing to repay hundreds of thousands of dollars to break their beverage contracts. ${ }^{36}$ Thus, even with effective third party mediation by well intentioned private parties and alliances with special interest groups, whole generations of American school children will continue to suffer the long term detrimental impact of constant exposure to foods with little or no nutritional value.

\section{NUTRITION AND PHYSICAL ACTIVITY: ESTABLISHING EFFECTIVE POLICY}

\section{A. Crafting School Health Policies: An Art And a Science}

State and local governments have an essential role to play in crafting school health policy relating, not only to beverage contracts, but also to nutrition and physical activity. The Child Nutrition and WIC Reauthorization Act of 2004 (the "2004 Act") required all local school districts participating in the Child Nutrition Act of 1966 to establish a school wellness policy by the beginning of 2006. ${ }^{37}$ This federal law appears to encourage more state and local involvement. For example, the Act requires schools to develop local wellness policies; however, under the 2004 Act, local school districts retain local discretion in interpreting "wellness" and in implementing wellness programs. ${ }^{38}$ The 2004 Act contains no enforcement provisions, but requires schools to maintain certain nutrition guidelines and create health goals relating to nutrition education and physical activity. ${ }^{39}$

State governments, then, have plenary power in designing and implementing school wellness policies. Health policies include laws and regulations as well as informal and formal rules and social norms. ${ }^{40}$ Health policies also include written standards designed to guide the choices of educators and school administrators by helping them to challenge unwritten social norms. For example, health policies would allow a school principal to designate additional lunch time for teachers to exercise. ${ }^{41}$ Despite the states' power and interest in protecting the health of their citizens, however, wellness policy is not without fault. For example:

[Sixteen] states have set nutritional standards on competitive foods [higher than those set by the federal government] while 20 states have set time and

36. Id.

37. Child Nutrition and WIC Reauthorization Act of 2004, Pub. L. No. 108-265, § 204, 118 Stat. 729 (2004).

38. Child Nutrition and WIC Reauthorization Act $\S 204$.

39. Child Nutrition and WIC Reauthorization Act $\S 204$.

40. Thomas Schmid et al., A Framework for Physical Activity Policy Research, 3 J. Physical ACtivity \& Health (Suppl. 1) S20, S27 (2006).

41. See id. at $\mathrm{S} 22$. 
place restrictions.... [but] only 10 states have rules that apply at all grade levels, and [at] all times of the day, throughout the entire school. ${ }^{42}$

Moreover, even that legislation is not necessarily effective, as enforcement of nutritional laws is apparently a low priority in budget-strained schools subject to increased-testing standards. ${ }^{43}$ For example: "A 2001 government review revealed that only 15 percent of elementary schools and 13 percent of secondary schools met the NSLP [National School Lunch Program] program requirements for saturated fat." ${ }^{, 44}$ Such violations are common because, in the words of Former Assistant Secretary of Agriculture, Carol Tucker Foremon:

[T] he 'USDA has very few tools to require compliance'... if the USDA refused to provide federal support to noncompliant school districts, 'the burden would fall not on the school system personnel who've failed to meet the rules but on poor children who depend on school lunch to get enough calories. ${ }^{45}$

Clearly, the lack of enforcement provisions in the 2004 Act hinders the effectiveness of Federal and state policies governing school nutritional guidelines.

\section{B. Time, Talent, and Resources: Recognizing the Problem is Only Half the Battle}

In addition to the challenges posed by attempts to implement nutritionally conscious policies and programs, schools also face another obstacle; overloaded academic schedules that seem to necessitate a decreased emphasis on physical education. With classroom academic time at a premium, state physical education requirements are often decreased. ${ }^{46}$ Currently, forty-eight states require physical education in schools, but there are great disparities in the guidelines defining what constitutes sufficient physical education ${ }^{47}$ In effect, this means that physical education programs in disparate states rarely require the same amount of physical education, and often impose differing requirements on

42. Simon \& Fried, supra note 3, at 140-41 (discussing variations in state wellness legislative activity).

43. See generally Paul D. Houston, Getting on the Right Track, SCH. GovernanCE \& LEADERSHIP, Spring 2006, at 6-8, available at http://www.aasa.org/files/PDFs/Focus/SG\&L _Spring \%2006.pdf (last visited Feb. 10, 2008).

44. Fried \& Simon, supra note 26, at 1514.

45. Id.

46. Houston, supra note 43 , at 6-8.

Time spent on physical education and health education is time taken away from academics. Federal academic mandates, such as those incorporated into No Child Left Behind ["NCLB"], have put the focus squarely on basic academic achievement, and many districts have responded by cutting physical education ... and other non-academic programs. ... The government has the big stick ... NCLB has come at the expense of ... physical education.

Id.

47. Houston, supra note 43 , at 6. 
which grade levels receive access to physical education. In response to these disparities: "In 2005, at least 39 states considered legislation related to physical activity or physical education in schools, and at least 21 of those states enacted legislation or passed resolutions" intended to strengthen school physical education requirements generally. ${ }^{48}$ Consequently, it is not surprising that a 2000 School Health Policies and Programs Study ("SHPPS") reported that, "only $6.4 \%$ of middle schools provided daily $\mathrm{PE}$ [physical education] for the entire school year, whereas $15.5 \%$ offered daily PE (or its equivalent) for at least half the school year." ${ }^{, 49}$ In response to the apparent inability of states to reach a consensus on the issue of physical education, an amendment to the No Child Left Behind Act was recently proposed at the federal level. ${ }^{50}$ The proposed amendment-the Fitness Integrated with Teaching Kids Act, H.R. 3257-would "require that all schools, districts and states include the quality and quantity of PE in the 'report cards' currently sent to parents." the American Heart Association, and would also fund research for reducing childhood obesity. ${ }^{52}$

Overloaded academic schedules notwithstanding, states often lack the funding necessary to ensure that physical education initiatives are being adequately executed. ${ }^{53}$ Moreover, in addition to the lack of funds necessary to increase enforcement of physical activity in public schools, state legislatures also face intense political and lobbying pressures to support the soft drink and snack food industries. Specifically, inexperience in negotiating mutually beneficial financial partnerships and the absence of incentives designed to encourage schools and corporations to work collaboratively, combined with a current lack of wellness policy "infrastructure" and a poor understanding of the importance of wellness-driven legislation, all constitute barriers to establishing successful wellness policy at the state and local levels. ${ }^{54}$

\section{State Attempts to Resolve the Youth Obesity Crisis: Legislative Mandate is the Key}

Receptivity to wellness legislation is mixed as some states embrace aggressive legislation, while others defer to a strong soft drink and snack food industry. In Arkansas for example, a 2003 law-Act 1220 -made Arkansas

48. Id.

49. Pate et al., supra note 20, at 1215.

50. FIT KIDS ACT, supra note 19.

51. Id.

52. $I d$.

53. See generally Houston, supra note 43, at 6-8.

54. See generally Fiona C. Bull et al., Implementing National Population Based Action on Physical Activity - Challenges for Action and Opportunities for International Collaboration, 13 PROMOTION \& EDUC. 127 (2006), available at http://www.minsal.cl/ici/destacados/curso _acti vidad_fisica/Bull_final.pdf (last visited Feb. 10, 2008). 
the first state in the country to promote comprehensive measures intended to address childhood and adolescent obesity. ${ }^{55}$ Act 1220 had three goals: (1) to enhance children's school environment by teaching healthy habits; (2) to engage parents and the community in encouraging children's health; and (3) to enhance the awareness of child and adolescent obesity in order to establish funded support structures. ${ }^{56}$ Act 1220 mandated that public schools collect information regarding students' body mass index, information that was later communicated to the students' parents. ${ }^{57}$ This mandate, while initially controversial, utilized a well-received comprehensive support system and unique informational technology in aiding the legislature in accomplishing its goals. ${ }^{58}$ As a result, by 2003, after only one year of implementation, Act 1220 was regarded as a successful statewide intervention in the fight against youth obesity and overweight, ${ }^{59}$ and by 2005 , ninety eight percent of the public schools in Arkansas were participating in the BMI assessment regime. ${ }^{60}$

Conversely, in Indiana, the collection of BMI information on public school students was not mandated by law. Instead, because it lacked the support of a legislative mandate, the Indiana State Department of Health and the Indiana Department of Education merely requested that Indiana public schools collect height and weight for all enrolled students. ${ }^{61}$ As participation in the BMI data collection effort was voluntary, the vast majority of Indiana's public schools declined to collect height and weight data on their students. ${ }^{62}$

Clearly, Arkansas's successful effort to mandate the collection and dissemination of BMI data on students in public schools differed dramatically from the non-mandatory-voluntary-BMI data collection efforts in the state of Indiana. Indeed, even a superficial comparison of the two initiatives makes it clear that the variation in political receptivity among legislators dramatically affects the ability of schools to collect consistent, reliable data on child obesity and overweight.

55. Child Health Advisory Committee Act of 2003, ARK. ANN. CoDE. § 20-7-133-135

56. The 2005 Arkansas Assessment of Childhood and Adolescent Obesity, EXECUTIVE SummaRY (Ark. Ctr. for Health Improvement, Little Rock, Ark.) 2005, at 6 [hereinafter The 2005 Assessment]. See generally ACT 1220 Summary, ARK. CENTER FOR HEALTH IMPROVEMENT, http://www.achi.net/current_initiatives/BMI_Info/Docs/ACT_1220_Summary .pdf (last visited Feb. 10, 2008).

57. See generally ACT 1220 Summary, supra note 56.

58. See generally id.

59. James M. Raczynski et al., Establishing a Baseline to Evaluate ACT 1220 of 2003: An Act of the Arkansas Generally Assembly to Combat Childhood Obesity, REP. (Coll. PUB. HEALTH, U. Ark. for Med. Sci., Little Rock, Ark.), 2005, at 10, available at http:// www.uams.edu/coph/reports/2004Act12202003Y1Eval.pdf.

60. The 2005 Assessment, supra note 56, at 1.

61. Terry W. Zollinger et al., Obesity Related Data in Indiana: A Resource Guide, REP. (Ind. St. Dep't. Health, Ind. Univ. School Med. Dep't. Fam. Med., Indianapolis, Ind.), 2007, at 13, available at $\mathrm{http} / / \mathrm{www}$.in.gov/isdh/programs/cnop/pdfs/ObesityResourceGuide.pdf.

62. Id. 


\section{CReating a Solution to the CRISIS OF YoUTH OBESITY AND OVERWEIGHT}

\section{A. Funding is Important but Real Change Will Necessitate a Paradigm Shift}

Creating an effective solution to the youth obesity crisis is critical, costly, and frequently confusing. The Trust for America's Health Chronic Disease Directors reports: "[E]fforts to combat the obesity crisis will not be successful until there is a real paradigm shift, with a sustained focus on well-funded, longterm approaches, a revitalized research agenda that emphasizes longitudinal studies, and a fresh look at what constitutes "success" and how it is measured.",63

Decreasing funding and political opposition for the development, implementation, and evaluation of large-scale obesity studies are monumental barriers to finding comprehensive solutions. Even the CDC - a federal agencyand its National Center for Chronic Disease Prevention and Health Promotion ("NCCDPHP"), both charged with the task of promoting health by preventing and controlling disease, have declining budgets for obesity-related programs. ${ }^{64}$ In fact, the NCCDPHP budget is equal to a meager three dollars per person annually in the United States, "which is less than the cost of most fast-food meals." 65

\section{B. The CDC's Efforts to Change National Preconceptions About Youth Obesity and Overweight: The Social-Ecological Model}

Funding issues notwithstanding, the CDC does provide a structured framework for state governments seeking to establish comprehensive nutrition and physical activity programs. The CDC currently provides twenty-eight states with funds necessary to address obesity using a variety of CDC approved nutrition and physical activity strategies, including public school interventions. ${ }^{66}$ Specifically, the CDC funds states which use a social-ecological model to address obesity. ${ }^{67}$ The social-ecological model addresses youth obesity and

63. Levi et al., supra note 11, at 53.

64. Id.

65. Id.

66. Ctr. For Disease Control \& PReVention, State Based Programs: CDC's StateBASED NutRITION AND PHYSICAL ACTIVITY PROGRAM TO PREVENT OBESITY AND. OTHER CHRONIC DISEASES, http://www.cdc.gov/nccdphp/dnpa/obesity/state_programs/index.htm (last visited Feb. 10, 2008).

67. Id. ("From individual behavior change to changes in public policy, state efforts aim to engage multiple levels of society; this is called the Social-Ecological Model, and it is a cornerstone of our approach."). 
overweight using a five-tiered protocol designed to instigate change at the societal, community, organizational, interpersonal, and individual levels. ${ }^{68}$

The social-ecological model's first level requires change at the societal level. ${ }^{69}$ At the societal level, the CDC advocates individuals, organizations, and communities working together to create nutrition and physical activity legislation and statewide school policies. ${ }^{70}$ At the second or community level, the CDC funds states working to improve environmental conditions, through strategies designed to improve such things as recreation facilities or accessibility to inexpensive and abundant produce. ${ }^{71}$ The social-ecological model's third level involves organizational changes such as increased school sports teams or increased physical activity at a local level, while at the fourth level, interpersonal groups such as families and friends encourage each other in healthful behaviors. $^{72}$ These fourth level interventions may be especially important in light of a recent study showing that obesity and thinness are "socially contagious" in family and friend situations. ${ }^{73}$ The final level of the CDC's social-ecological model is the individual level, at which the CDC suggests obesity and other chronic diseases can be addressed by changing individual behaviors. ${ }^{74}$

\section{The CDC Wages War on Obesity}

The CDC's willingness to offer federal monies in support of school-based obesity initiatives has been an essential element in the war on youth obesity and overweight. Indeed, the CDC's support has provided essential support to school-based initiatives in several ways. First, the CDC's support has facilitated the creation of a "Coordinated School Health Program," which teaches schools and communities how to create healthier school environments through the integration of community and family involvement. ${ }^{75}$ Second, the CDC's support has lead to the development of a "Physical Education Curriculum Analysis Tool" which helps school districts evaluate their physical education curriculum based upon national physical education standards. ${ }^{76}$ Schools can then use the results of this tool to enhance existing curricula or to develop new

68. Id.

69. CTR. For Disease Control \& Prevention, OVERWEight AND OBestTy: STATE Based PROGRAMS: SOCIAL-ECOLOGICAL MODEL, http://www.cdc.gov/nccdphp/dnpa/obesity/state_pro grams /se_model.htm [hereinafter Social-ECOLOGICAL MODEL] (last visited Feb. 10, 2008).

70. $\bar{I} d$.

71. Id.

72. Id.

73. See generally Nicholas A. Christakis \& James H. Fowler, The Spread of Obesity in a Large Social Network Over 32 Years, 357 NEw ENG. J. MED. 370-79, (2007).

74. SOCIAL-ECOLOGICAL MODEL, supra note 69.

75. Ctr. For Disease Control \& Prevention, See Healthy Youth!: Funded Partners: States, Territories, and Localities: CoOrdinated School Health Programs, http://www.cdc.gov/HealthyYouth/partners/funded/cshp.htm (last visited Feb. 10, 2008).

76. Id. 
programming. ${ }^{77}$ Finally, the CDC has awarded an average of $\$ 416,000$ in "Division of Adolescent and School Health" ("DASH") cooperative agreement funds to twenty-three states in 2006. ${ }^{78}$ The U.S. Department of Education works with DASH-state departments of health to create school-based policies and programs addressing youth obesity. ${ }^{79}$

States utilizing CDC funding are using creative strategies to address solution-resistant youth obesity. For example, the Colorado Physical Activity and Nutrition Program ("COPAN") utilized CDC funding to support rural communities such as Commerce City, where low-income preschool students-a population largely understudied - and their parents are offered nutrition, cooking, and literacy programs. ${ }^{80}$ Not all states, however, are using the CDC funding and support as the sole source of creative solutions designed to address youth obesity at the school level. One appetizing Boston-based program is funded by the Boston Public Health Commission and Project Bread. ${ }^{81}$ Under that program, a top Boston restaurant chef is working with school cafeteria managers to teach them how to cook nutritious, flavor-rich, meals such as chicken parmesan pizza and hummus. ${ }^{82}$ It is hoped that school cafeteria managers will then replace the traditional greasy cafeteria fare of burgers, fries, French toast sticks, and smoky links with less traditional healthier alternatives. ${ }^{83}$ The chef also takes photos of the actual food and hangs them on the school wall, so children will be exposed to the healthy foods in a visual way. ${ }^{84}$

Indiana, on the other hand, is taking a different approach to educating students about good nutrition. Indeed, rather than relying on CDC funding and support exclusively, Indiana is also using its own high school students to teach younger students the importance of proper nutrition. These students, known as the INsight Youth Corps, are working, under a state based initiative, "to provide experience-based learning, enhance personal and academic achievement, and build leadership skills among its members, preparing them for future success and commitment to lifelong healthy lifestyles and health advocacy." ${ }^{, 85}$ The INsight Youth Corp is a branch of Governor Mitch Daniels' statewide health initiative, INShape Indiana, which provides a one-stop-shop for finding Indiana-based physical activity, nutrition, and tobacco prevention and cessation information.

77. Id.

78. Levi et al., supra note 6 , at 35 .

79. Id.

80. CTR. For Disease Control \& PREVENTION, Overweight AND OBesity, http://www. cdc.gov/nccdphp/dnpa/obesity/state_programs/about_us.htm (last visited Feb. 10, 2008).

81. J.M. Lawrence, Schools Hope Chef's Touch Whets Cafeteria Appetites, Boston GLOBE, Sept. 13, 2007, available at http://www.boston.com/yourlife/health/fitness/articles/ 2007/09/10/schools_hope_chefs_touch_whets_cafeteria_appetites/(last visited Feb. 10, 2008).

82. Id.

83. Id.

84. Id.

85. STATE OF IND. INSHAPE IND., INSIGHT YOUTH CORPS, http://www.in.gov/inshape/2344 $\mathrm{htm}$ (on file with the author). 
What public school wellness programming options do states not funded by the CDC have? In 2002, Congress asked the Institute of Medicine ("IOM") to develop a prevention-focused action plan to decrease youth obesity in the United States. ${ }^{86}$ The IOM responded by developing interventions for use by the federal, state, and local governments. ${ }^{87}$ At the federal level, the IOM suggested developing an interdepartmental task force to coordinate federal actions with regard to school wellness programs. ${ }^{88}$ It also suggested that the federal government expand funding for prevention intervention research, experimental behavioral research, and community-based population research. ${ }^{89}$ At the state and local government level, the IOM recommended encouraging opportunities for physical activity in the community, through changes in ordinances and capital improvement programs. ${ }^{90}$ Under these interventions, schools were encouraged to improve the nutritional quality of food and beverages and to implement school-based interventions which would decrease "screen time." also recommended that schools conduct annual assessments of students' weight, height, and BMI, in addition to ensuring that all children and youth participate in a minimum of thirty minutes of moderate-to-vigorous physical activity during the school day. ${ }^{92}$ The IOM also designed interventions for media outlets and the food industry generally. ${ }^{93}$ Specifically, the IOM encouraged industrial entities to develop healthier foods, while at the same time working with media outlets to expand consumer awareness of nutritional information. ${ }^{94}$

To implement successful wellness policy, scientists, lawyers, and legislators must work together in understanding current research. An article in the Journal of Physical Activity and Health suggested a starting point for policy formation, stating that: "A popular model of policy development ... describes three interrelated factors that are thought to influence the development, implementation, and outcomes of policy: the knowledge base (research/evidence), social strategy (effective interventions/solutions) and political will." 95

\section{CONCLUSION}

More federal and state funding is needed to increase the research and evidence knowledge-base related to youth obesity and overweight. Effective in-

86. Preventing Childhood Obesity: Health In The Balance, REP. BRIEF (Inst. of Med., Washington, D.C.), 2004, at 1, available at $\mathrm{http}: / \mathrm{www}$. iom.edu/Object.File/Master/25/858 /Childhood\%20Obesity\%204-pager-fix\%20for\%20web\%20pdf.pdf(last visited Feb. 10, 2008).

87. Id. at 2-3.

88. Id. at 3.

89. Id.

90. Id.

91. Id.

92. Id.

93. Id.

94. Id.

95. Schmid et al., supra note 40 , at $\mathbf{S} 28$. 
terventions and solutions are imperative, but to be successful, states and practitioners must follow Arkansas's bold lead and disseminate intervention on successful youth obesity interventions to others. Moreover, the American Heart Association's scientific statement on promoting physical activity accurately summarizes the role schools must play to ensure that obesity is not allowed to remain, as Dr. Richard Carmona suggested, the terror within:

Schools are potentially attractive settings in which to promote positive health behaviors because students spend large amounts of time in the school environment, elements of the traditional school curriculum relate directly to health, and schools typically provide extracurricular programs that can promote health...Disquieting trends in other segments of American society, such as increased "screen time" and decreased reliance on physically active transport, indicate that the schools should assume a leadership role in ensuring that young people engage in adequate amounts of physical activity each day. This statement advances policy initiatives that, if fully implemented, would position American schools as societal leaders in addressing an enormous public health challenge. ${ }^{96}$

Furthermore, as laws regarding the prevention and treatment of youth obesity and overweight can change with each electoral cycle, politicians, at all levels of federal, state, and local government, must be willing to reach the compromises necessary to establish stable health policies. Finally, governors, legislators, and educators - in addition to families and individual students - must demand adequate funding for further research into the expanding youth obesity problem in America. 